\title{
PROBLEMS IN BIOTECHNOLOGY RESEARCH
}

\author{
Parveen Jamal and Hamzah M. Salleh
}

Kulliyyah of Engineering, IIUM, Malaysia
jparveen@iiu.edu.my; hamzah@iiu.edu.my

\begin{abstract}
To meet the challenges posed by the growing population of the world, biotechnology research is being pursued in all countries. In the area of medicine remarkable success has been achieved. It is believed that in future this trend will continue. In the area food also scientists and technocrats have shown considerable success, but in this area they have not received appreciation because of many objections. The paper discusses issues pertaining to biotechnology researches, because if these issues are not thoroughly discussed and problems are not hammered out, biotechnology researches will go on but will fail to serve the humanity.
\end{abstract}

Key Words: biodiversity, biotechnology, cloning, germ cell, genetic materials, biosafety.

\section{PRELUDE}

With the increase of population of the world, food demand is also increasing. This phenomenon will continue. In times to come, contrary to developed countries, the food demand in developing countries will escalate, because in developed countries, the population will stabilize and developing countries' population will keep on growing at 3 to 4 per cent per annum. This phenomenon will demand building more and more settlements and related infrastructures and facilities to ensure comfortable living. For this, we will have to sacrifice our agricultural lands and forests to the sustainable extent. The increased population will demand a healthy environment, health promotion facilities both prevention and cure. If these demands are not met amicably, the world will confront with a disastrous situation and the developing countries will be immensely hit from the afflictions and sufferance. Only biotechnology scientists can avert this type of situation and they are making their best efforts. All states, including developing countries like Malaysia, have increased their biotechnology budget allocations, and they are providing all kinds of facilities to their scientists to spearhead as fast as possible. It seems that after the information and communication technology, including the computer engineering, the era that is knocking at the door of the k-economy is the biotechnology engineering, especially its area of gene manipulation and bio-pharmaceuticals.

But the biotechnology engineering is suffering from various problems and challenges - legal, social, religious and ethical, economic, and scientific. The purpose of writing this paper is to highlight some of those problems and to make modest attempts to find possible pragmatic solutions to them.

\section{LACK OF INTERNATIONAL COOPERATION}

Developed countries are resourceful and technologically advance. Because of these, they are playing a leading role in the area of research and development pertaining to biotechnology. International cooperation in this area is not significant at all. Developed countries do not subscribe to the idea of transparency in the area of biotechnology. The reason that seems to be conspicuous is economic; compassion has no influence on them. These countries want to cash their research. The episode of supply of medicine for curing AIDS in some African countries proves this. The problem has aggravated from the fact that most of the researches are in the private sector, and companies as business organizations have a predominant profit motive. This is evident from the fact that some American companies earned billions of dollars from their researches in the area of medicine and vaccines. They did not fairly share their income with the developing countries from where they collected the relevant genetic materials. Their attitude can change only when governments interfere. But why will governments interfere? That stage is yet to come.

It is better if researches are conducted as a joint venture between scientists of developed and developing countries work together in certain specified areas. This is possible in both the ways, arranged between private sectors and between government owned institutions, like public laboratories, research institutions and universities. It will be better if collaborations are done through respective governments. There is a recent example of this kind. Indian scientists in collaboration with some American scientists have developed a vaccine for prevention of infection from HIV. They have significant breakthrough in developing the vaccine. Test has successfully been conducted on mice, and before it is tested on humans, as a second step, tests on monkeys are in progress. This practice will certainly have a greater degree of transparency, and if liberally applied, will immensely serve the humanity. Another recent significant research is invention of vaccine for Parkinson disease by a group of scientists in New Zealand. The author feels that profit motive 
should be there, because this will encourage scientists to venture in the area of biotechnology. But the element of compassion should totally be thrashed out. So as to bring them together, cooperation between developed and developing countries become crucial. For this, initiatives will have to be taken by developed countries.

\section{SHARING BENEFITS}

This has been pointed out above that private sector companies in the West and other developed countries have successfully conducted most of the biotechnology researches and they are reluctant in sharing benefits of the researches with the countries from where they collected genetic materials. The Convention on Biodiversity (CBD) provides for collection of genetic materials on the informed consent basis under a specified procedure. It also provides, on this basis, to share profits accruing from biotechnology researches. For implementing this provision, states have to make law. If a plant or animal is found in a region, all countries of the region should have similar legislations and should cooperate in preventing smuggling of that plant or animal or its body parts. The object of the law should not be to defeat the research, but to facilitate it. In this context, the attitude of private companies in the west has to be changed. The whole process will work equitably only when flexibility on both the sides is observed. It will be better for those companies to establish laboratories in developing countries where genetic materials exist. These laboratories should conduct researches, should manufacture end products, and should market them from the developing and under developed countries. Respective developing countries should share the copyright, and there should be joint patenting of products. If this is practiced, developing countries will have confidence, there will be equitable distribution of profits, and the area of biotechnology research will flourish fast.

\section{TRAINING OF BIOTECHNOLOGY SCIENTISTS}

This is also a cooperation area that is highly demanded. Although sincere efforts in developing countries in the area of biotechnology research are being made, scientists in theses countries are handicapped for two reasons: lack of enough financial resources, lack of sophisticated equipments and lack of truly competent scientists and technocrats. Many developing and less developed countries cannot afford the cost of necessary equipments; and many others can afford the financial burden, but due to lack of enough trained human resources, cannot pursue research and development activities. They can get them only on the basis of liberal transfer of technology. But unfortunately the process of transfer of technology is utterly slow. Developed countries want to sell technology; they do not want to provide for free. For this, they find a pretext and say that technology is mainly in private sector and they do not want to interfere. Likewise, due to lack of experts in the area, the training of the younger generation scientists is awfully slow. The situation can improve only when developed countries show enough political will and meaningfully facilitate both the aspects. The CBD mentions about it in the area of conservation of the biological diversity of the world, which is the basic foundation and genetic materials for biotechnological researches, the Conference of Parties (COP) has not been able to come up with a meaningful breakthrough. The author is of the opinion that the monopolistic approach of the west will create a situation, in the long run, when the third world population will either be a burden on developed countries or will virtually become slave of the west. Developing countries should also do their best to provide impetus to biotechnology researches. For this, they should strive hard to develop international cooperation, to woo their scientists working outside their countries, to attract foreign scientists, to provide incentives to those who are working in this area, to encourage local scientists and technocrats, to provide scholarships to excel in this area. It is not impossible. Most of the developing countries, including Malaysia, have potential and capability to do all these and they are doing. South-south cooperation can also help to some extent.

\section{BIOSAFETY}

This is one of the pertinent problems related to biotechnology. If a biotechnology research is not safe to man and other living organism, as the case may be, the research will become a curse rather than a boon. Because of this reason, biosafety has become a priority issue. It is notable here that the African country Zambia has opted to starve rather than accepting genetically modified corn for their people. It has asked the World Food Programme (WEF) to take away the GM corn supplied to them, half of that is already in warehouses. Whereas, Malawi, Lesotho, Mozambique and Zimbabwe have decided to accept milled grains rather than intact corn. The restrictive measures adopted by African countries have posed a social problem. Will it be advisable for them to try and see the effect of the GM corn? On the contrary, will it be appropriate to let the starving people die of hunger? It is argued by the relief providers that in the United States alone millions of tonnes of GM corn, tomatoes and other GM food are consumed annually. But the NGOs based in Europe have never been favorable to GM food. They always speak against such food. That has generated a lot of doubts in the minds of people and governments around the world. In fact, people are scared of such food now. These NGOs argue that each state should take its own decision. United States has angrily condemned the Zambian decision and the attitude of the NGOs. This has given rise to a controversy. The US Agriculture Secretary and Andrew Natsoin of the US Agency for International Development have branded the act of NGOs as misinformation and disgraceful. While reacting against such comments, Geert Ritsema, a campaigner of GM 
issues for Friends of Earth Europe, said it was unfair and untrue to target green groups this way. Once the United Nations got embroiled in the debate when one of its officials, Jean Ziegler declared GM food dangerous to the human organs. Contrary to this, Gro Harlem Brundtland, Director General of the WHO holds the view that GM food can safely be eaten.

Here a question arises: why the African courtiers are so scared of genetically modified food? The answer seems to be simple. Those who have developed such food have not come up with the guarantee of its safety. Had the safety tests been meaningful, transparent and positive, there would not have been such hue and cry. The burden of testing the safety of genetically modified food primarily lies on those who have developed them. It is their ethical as well as moral duty. This should be indisputably be made a legal duty as well. Prominent among the genetically modified food are: corn, soybean, tomato and cottonseeds (for oil). Producers want to market them and products containing them without guaranteeing their safety aspects. The task of biosafety tests is not difficult. Producers can conduct it, and it can be done by other agencies (for example, NGOs) having competent scientists as well. But while doing this, vested interests and politics should be kept away. For example, a company wants to market its genetically modified mustard oilseed in India. When Indian scientists and farmers created hue and cry, the government postponed its ingress in the country. Likewise, attempts are being made to foster BT Cotton in the Indian market. It is claimed that in the BT Cotton has a kind of toxin its own that kills harmful insects. But the company, which has developed this, does not have satisfactory answer about the following related aspects: What will happen if insects develop immunity? Will the oil extracted from their seeds be safe for eating?

Another related aspect is maintaining purity of indigenous varieties. Pollens of genetically modified varieties will contaminate the local ones. There is a simple answer to this objection: maintain a buffer around the genetically modified varieties. But this is possible only when there are big farmers venturing in a big chunk of land. What about the places where farmers have small landholdings? In countries like India and for that matter other developing countries, there are smallholdings; the idea of keeping buffer around genetically modified verities cannot be practiced effectively.

Under the Biosafety Protocol, which has been made under the CBD, requires from the member states to adopt certain measures that ensures safety of human health and conservation of the environment as such. Thus, measures have to be taken for ensuring the safety of invented living modified organisms (LMOs). The Protocol authorizes states to adopt restrictive measures about transboundary movements of such LMOs. In spite of this international law, private companies for their vested interests are striving hard to avoid the treaty norms of the Protocol. Unless this attitude is changed, the protocol or any other development of law in that direction will not yield the desired result.

In view of the above paragraphs, it is suggested that the biosafety issue should be given priority. Efforts should be made to develop food varieties that are satisfactorily safe. Profit motive should not dominate the safety issue. If we produce a lot, but if that lot cannot be used, that lot will be of no use. Because of this reason, some scientists prefer developing superior species of plants and animals by way of cross-fertilization and grafting. The authors feel that this area of research should not be neglected. But it cannot be the sole area of research. We will have to resort to the gene manipulation technology to enhance the development of superior species of plants and animals mentioned above.

\section{PATENTING OF LMOs AND GM FOOD}

According to the patent law prevalent in almost all countries, innovations can be patented. This protection has been provided for inventors so that they could enjoy the fruits, in terms of money, of their inventions. In view of the process of globalization and preventing the inventions internationally, the Agreement on Trade-Related Intellectual Property Rights (TRIPS) was signed in 1992 at the time of the Rio Conference. Now, every LMO can be patented and thus protected from duplication and other kind of unlicensed use. With the result of this development, big biotechnology companies are protected. They have the monopoly of their inventions. Other persons can even use them only on their permission. It is for this reason that such patenting is considered as non-friendly to developing countries and poor peasants of those countries.

We know the Basmati rice episode. Patenting of this variety of rice by an American company was an attempt to deprive poor peasants of India and Pakistan who had been growing this rice from the time immemorial and ultimately to deprive these two countries from exporting this kind of rice. Due to largescale protests in two countries, it was ultimately decided by the competent authority in the United States of America that only invented variety of rice could be patented; the varieties that already exist cannot be patented. This gave a shy of relief to Indian farmers. A similar problem arose when some companies in Europe patented pesticides made from neem trees. Indian and Pakistani farmers were already using a natural pesticide prepared from various parts of neem tree. This was a gross violation of their customary right and a misuse of the patent law. Only after a long representation by these countries and interest groups it was held that the patenting was legally wrong.

The story of termination seeds is annoying. Termination seeds will make farmers totally dependent on the companies that have invented them, because from the crop farmers cannot get new seeds. Every growing season they will have to buy seeds from the respective companies or from their dealers. This will provide clear chance to biotechnology companies to economically exploit poor farmers. Another great loss 
will be the vanishing of indigenous varieties. If in future, for biotechnology research purposes local seeds are required, they would not be available. This will be a great handicap to the field of biotechnology engineering. The situation will be something like what was experienced in Cambodia. Here the farmers selected one or two of the local rice varieties. With the result of that, all other varieties vanished. It was a big handicap for scientists for conducting research on improving upon the existing indigenous rice species and inventing entirely new species. Fortunately those vanished rice varieties were there in the International Rice Gene Bank in the Philippines. Scientists took genetic materials from the gene bank and conducted their research.

\section{PROTECTION TO THE ENVIRONMENT}

New LMOs have some qualities in them. One of these is to survive in adverse weather conditions. If such LMOs are not used with strict precautionary measure, there will be all chances that other varieties will be overwhelmed by the new variety. This may happen in both, plants and animals. It is, therefore, suggested that before introducing such varieties into the environment, their impacts on other similar and other species should be thoroughly assessed. Otherwise the new variety will survive and other varieties will vanish. Likewise, when a new variety is to be introduced, it should be ensured that other similar varieties would also survive side by side. This phenomenon has in happened in South Africa. Here a variety of tree was brought into the country for plantation purposes. The weather of the country so suited to the imported plant variety that it overwhelmed the local diversity in the same kind of trees. So as to protect them, the whole lot of the imported variety had to be destroyed. Likewise, in the United States, scientists of the University of South Carolina on the basis of a research conducted by them have revealed that on many occasions GM crops crossed their boundaries and cross-pollinated the normal plants to create 'super weeds' that are resistant to insect attack and could spread rapidly. This shows that the growing GM crops might be sheer destruction of the environment if not properly controlled and thoroughly assessed.

\section{RIGHT TO INFORMATION AND BIOTECHNOLOGY}

Because of lack of transparency in scientific safety findings, people are scared of genetically modified food (GM Food). They assert their right to information and want to know about what they are eating. Some want to know it for religious reasons. Muslims also want to know it, because if impure genetic materials have been used for developing LMOs, they will not be halal (permitted) for Muslims. Some countries have enacted law for declaring input of genetically modified stuff in food. So every product must disclose this fact. Some other countries, like Malaysia, are in the process of making such law. It is, therefore, suggested that engineers and technocrats should do an intensive scientific investigations about the LMOs, and findings should be repeated. There should be transparency in the whole process so that people could develop confidence in the edibles prepared from them or using them as one of the ingredients. All countries should make law to protect the right to information of their people.

\section{GENETIC ENGINEERING AND HUMAN CLONING IN THE LIGHT OF SHARIAH AND ETHICS}

Some ulama (experts of Muslim theology), who are actually in minority, hold the opinion that gene manipulation is interference in the domain of Allah. Thus, such acts are prohibited in Islam. On the other hand, some right-minded ulama, who really want to take care of the growing human mass, are of the opinion that use of this technology is a must, provided the injunction of Quran and sunnah (traditions of the Prophet) are not violated.

In view of this, it is necessary to investigate into the original sources in Islam and commentaries written on them. Genetic engineering has attracted lengthy discussions amongst Islamic scholars around the world. The issues pertaining to this branch of science have generated interests among scientists and religious scholars equally.

In Islam the biotechnology processes are questioned on the basis of the Quranic ayah, "Verily of thy servants I shall most certainly take my due share, and shall lead them astray and fill them with vain desires. And I shall command them so that they cut off the years of cattle (in idolatrous sacrifice), and I shall command them and they will change God's creation." (4:119). However, there is no consensus on the issue of total ban on genetic engineering. The author feels that genetic engineering is knowledge. This knowledge will not be acceptable unless it is not in conformity with Quran and Sunnah. It is submitted that beneficial aspects (in the form of safe and environment friendly biotechnology) are in no way against them. Rather, it has a predominant element of maslaha (public interest) in it, because demands fostering such biotechnological researches in Muslim countries are pressing now. Contrary to this, all kinds of cloning, human and animal, should be considered as interference in the domain of Allah (swt), as Allah has made a natural system of reproduction and the act of cloning is against that system. Cloning amounts to denial of Allah's wisdom. In 1998, in Kuwait a seminar was held on "Genetics, Genetic Engineering, the Human Genes, and Genetic Treatment - An Islamic Perspective" In line with the authors' view on biotechnology and cloning the following principles were approved. 1. Any tampering with man's basic constituents would be in violation of man's God given dignity (al-Quran, 17:70). 2. Islam is a religion of knowledge and science, which imposes no restrictions on constructive scientific 
research. Thus, Islam supports genetic engineering. 3 . Nobody's genes should be subject of research without evaluating its pros and cons. 4. No research on human genes or application of any such research should take precedence over the Shariah and the respect of human rights, basic liberties and human dignity of any individual or group of individuals. 5. The reading of human gene by mapping out the full genome is part of man's endeavor to understand him and appreciate God's power of creation. It is important for medical point of view also. 6. Genetic engineering may be used in the prevention, treatment or alleviation of diseases. Genetic engineering should not use germ cells (for example, stem cells of a premature fetus). 7. Genetic engineering should not be used for any sinister or offensive purposes, or crossing the genes boundaries between various species in order to produce hybrids or merely for sport or scientific curiosity. 8. Genetic engineering must not be used for changing the human structure. 9. Poor should also benefic from scientific researches.10. Islam does not object to the use of genetic engineering in the fields of agriculture and livestock, without ignoring, however, those voices that have recently warned of possible harmful long-term effects on man, animals, crop or the environment.

The declaration supported genetic fingerprinting, genetic counseling, and genetic diagnosis because they are in the interest of man. The conference recommended for promotion of genetic research in Muslim countries financially supported by governments and other financial institutions.

Among the views highlighted above and agreed by the participants of the Kuwait Conference, cloning and use of germ cells (also known as stem cells) obtained from premature human fetuses are highly objectionable. Thus all kinds of cloning and germ cell based researches should be prohibited. This may be noted that use of germ cells encourages for abortion of premature fetuses for small economic interest. There are rackets involved in this immoral and unreligious act. They are targeting developing and underdeveloped countries. Their main job is to collect such foetuses and to smuggle them to developed countries. In Bangladesh, some of these have been rounded up. But the process is continued even though the use of germ cells for biotechnological researches has been made illegal in many countries. Legally, although there is very little to stop scientists from cloning, in the United States, in January 2002, the National Academy of Sciences recommended a ban on human cloning. In pursuance to that, some of the American states, including California, Michigan and Louisiana, have enacted laws declaring human cloning as a banned activity. However, according to the existing law, germ cells collected only before $9^{\text {th }}$ August 2001 can be used for the approved kind of research. So is the case in Germany. Countries have taken prohibitory measures because they consider it unethical and it may have unwarranted scientific, social and economic consequences. For example, recently, scientists are doing research to create human mouse hybrid by infusing stem cells into an early mouse embryo when it is still a small ball of cells called 'blastocyst'. This way, the hybrid mouse will have tissues with human cells also (this is known as 'pluripotentiality'). This will help for conducting research to protect human being from some hereditary diseases. But some scientists are of the opinion that this might yield dangerous results if human cells radically change the mouse or if the mouse producing human sperms meets another mouse having human eggs. It is, therefore, suggested that Muslim scientists should keep themselves away from these. If they do so, there will not be any setback to the ongoing biotechnology research because other options are available. So far as cloning is concerned, in addition to the reason mentioned above against it that it is interference in the domain of Allah, it might be against the biodiversity also. For example, if a giant species is created, that species will overwhelm the existing species and a time will come when the situation will be no less than total disaster of the biodiversity of the environment. Another important aspect that needs to be controlled by all means is production, stockpiling and use of biological weapons. This is also against the Islamic teaching of environment and the Islamic law of war because it would affect innocent people. It is necessary, therefore, to destroy the existing stocks of these weapons and to abandon all kinds of research in progress

We have noted above that every biotechnological breakthrough will not be acceptable in Islam. Genetic materials used in the research must be obtained from halal objects by halal means. Thus, if genetic materials are taken from a pig or any other living object that Muslims cannot eat are prohibited to be used for genetic research. Vaccines are the significant biotechnology researches. But if the genetic material has been taken form a pig in order to manufacture any vaccine, the vaccine will be haram (prohibited) for Muslims. Recently, fatawa committees of some countries, including Malaysia, have declared the 'monomune vaccine', which is used to preventing meningococcal meningitis, as haram because it contains amino acids (proteins) derived from pigs, or from cows and duck not slaughtered in the Islamic way. This has been done because alternative to this vaccine by the name of 'mencivax' is available. 'Monomune vaccine' will be allowed to Muslims only when it is guaranteed that the protein used for manufacturing the vaccine was from a cow or a duck properly slaughtered. If no alternative is available and human mass cannot survive without that, the opinion might be different.

Activities that are considered to be prohibited in Islam are also considered as socially deviant activities. All socially deviant activities are immoral. Activities that are immoral in the area of human activities are considered as unethical also. Thus, activities that are considered as socially deviant in the area of biotechnology are unethical to biotechnology scientists. In Islam, Quran and Sunnah basically govern human conducts, human relations and human behaviors. 
These, thus, have to be compatible with the two basic sources of the Islamic shariah. Any social practice that opposes them is ultra vires and has to be prohibited, and its practice has to be dealt with severely.

\section{CONCLUSIONS AND SUGGESTIONS}

Biotechnology, in fact, is the need of the day. If intensive and speedy research in this area is not done, the growing population might create a chaotic situation that might then be difficult to solve. To meet the challenge, all countries, including Muslim countries, are making efforts in this area according to their ability. But developing countries due to limited number of trained scientists and technocrats, insufficient resources, and lackadaisical attitude of developed countries in the area of transfer of technology and financial resources are lagging behind. In developed countries, the area of biotechnology is generally in the private sector. Because of this, profit motive has overwhelmed the humanitarian and other considerations. This attitude is depriving many from their rights to have a safe environment and healthy food. It is, therefore, suggested that the biosafety aspect of biotechnology research is in no way less important than the research itself. It will be appropriate to double the efforts developing better quality of plant and animal species through cross breading and grafting. Biotechnology should be given a cautious approach so that some thing harmful is not introduced into the environment or brought for consumption. Before commercializing any product, thorough investigations from the point of view of safety should be done.

Somewhere biotechnology has entered into the arena of immorality. Scientists and technocrats there are keen to come out by any means any kind of research. This way, they have gained name but have failed to serve the humanity. Termination seeds, BT cotton and the like are the examples. This tendency should be abandoned. Likewise, malpractices of doing research on germ cells obtained from premature foetuses should be stopped. It will be in the fitness of the thing if biotechnology scientists, technocrats and others involved in biotechnology researches and marketing of their outcomes are given periodical religious orientation.

Recently, a scientist in the United States has claimed to have a conducted successful birth of a cloned baby girl, some others, according to an Italian Scientist, are on the way to take birth in the month of January. If this is proven to be true, this will be a perversion of science and socially and morally an outrageous and deviant behavior. It is thoughtless to justify cloning on the myth that life on the Earth was created through cloning by extraterrestrials. Presently, there is very little in the law to stop scientists from human cloning. If immediate restrictive efforts, at global level, are not made, the situation might be grave. Therefore, the authors are of the opinion that all kinds of cloning, including human cloning, should be banned with immediate effect.
Islam does not prohibit biotechnology research. Rather, the principle of maslaha encourages Muslim scientists to play a leading role in this area. If they take the lead, many evils that exist now will certainly vanish and humanity will receive the real reward of biotechnology researches. In Muslim countries, therefore, biotechnology research should be made a priority area and for fostering it all kinds of incentives should be provided.

\section{REFERENCES}

[1] A. H. Ansari and Parveen Jamal, "The Convention on Biological Diversity: A Critical Appraisal with Special Reference to Malaysia", Indian Journal of International Law, Vol. 40, pp. 137-145, 2000.

[2] T. Dobson, “ The Loss of Biodiversity: An International Environmental Policy Perspective", North Carolina Journal of International Law and Commercial Regulations, Vol. 17, pp. 34-49, 1992.

[3] S. H. Bragdon, "National Sovereignty and Global Environmental Responsibility", Vol. 33, p. 382, 1992.

[4] W. M. Flavares, "Ecosystems Economics and Ethics: Protecting Biological Diversity at Home and Abroad", Southern California Law Review, Vol. 65, pp. 204 263, 1998 .

[5] A. H. Ansari, "Scientific Aspects of the Convention on Biological Diversity: Perspectives and Challenges", in Proceedings of the International Symposium on Future Issues of Research in Science and Technology, Tokyo Institute of Technology, pp. 184-89, 1997.

[6] J. R. Kloppenburg and D. C. Cleinman, "Seeds of Controversy: National Poverty v. Common Heritage", in Jack R. Cloppenburg (ed.) Seeds of Sovereignty pp. 173-192, Cambridge, UK 1988.

[7] M. S. Swaminathan, "Biotechnology and a Better Common Present: A Synthesis", in I. P. Getubig, V. L. Chopra and M. S. Swaminathan (eds.), Biotechnology for Asian Agriculture, pp. 95-116, Asia and Pacific Development Centre, Kuala Lumpur, 1991.

[8] P. H. Yue, "Altering Genes in Food Crops", New Straits Times, 24 November 1998.

[9] D. A. Ramirez, "Biosafety: An Area of Concern", pp. 201-208, in Biotechnology for Asian Agriculture (supra).

[10] Suman Sahai, "How Do We Protect Our Resources", Economic and Political Weekly, 6 July 1996.

[11] A. J. Wells, "Patenting New Life Forms: An Ecological Perspective", European Intellectual Property Review, Vol 3. pp. 111-132, 1994.

[12] Youssef Ibrahim, "New Soya Bean Alarms Europeans", New Sunday Times, 17 November 1996.

[13] A. H. Ansari, Readings in Environmental Law, pp. 170-186, Subhashit Ankan, India, 1995.

[14] G. S. Nijar, "Biodiversity in Malaysia: Prospects and Problems", in The State of Environment in Malaysia, pp. 209-216, CAP, Malaysia, 1997.

[15] Joseph Edwin, "Will and Way in Biodiversity", New Straits Times, 20 September 1995.

[16] A. H. Ansari, "Contemporary Issues in International Trade Law and Environmental Law", Proceedings of 
International Conference on Law and Commerce, Jointly Organized by IIUM and Victoria University, pp. 121-139, CLJ, Malaysia, 2002.

[17] A. H. Ansari and Parveen Jamal, "Towards An Islamic Jurisprudence of Environment: An Expository Study", Religion and Law Review, Vol. 23, pp. 34-49, 2002.

[18] Proceedings of the Seminar organized by the Fiqh Academy, Jeddah and the Islamic Education, science and Culture Organization, Kuwait, Kuwait 13-15 October 1998. Reproduced at: www.Islamset.com.

[19] Richard Ingham, "GM food row clouds famine relief", New Straits Times, December 3, 2002. 